\title{
EVALUATION OF IN VITRO ANTIOXIDANT AND $\alpha$-AMYLASE INHIBITORY ACTIVITY OF PHYLLANTHUS INDOFISCHERI BENNET
}

\author{
KALPANA S, RAMAKRUSHNA B, ANITHA S $^{*}$ \\ Department of Biotechnology, Sri Krishnadevaraya University, Anantapur 515001, Andhra Pradesh, India \\ Email: anithasku@gmail.com
}

Received: 10 Jul 2016 Revised and Accepted: 09 Sep 2016

\begin{abstract}
Objective: The present study evaluates the antioxidant and $\alpha$-amylase inhibitory activity of leaf and bark extracts of Phyllanthus indofischeri with methanol and water as solvents. In addition to this, the total phenolic content and total flavonoid content was determined.

Methods: The total phenolic and total flavonoid content of the extracts was determined by folin ciocaletus reagent method and aluminium chloride colorimetric method respectively. The antioxidant and $\alpha$-amylase inhibitory activity were measured by various assays, including $\alpha, \alpha$-diphenyl-0 dipicryl-hydrazyl (DPPH) free radical scavenging, 2,2'-azino-bis(3-ethylbenzothiazoline-6-sulphonicacid) (ABTS) radical scavenging, superoxide radical scavenging, total antioxidant capacity by phosphomolybdate method and porcine pancreatic $\alpha$-amylase inhibitory assay. The IC ${ }_{50}$ values were calculated and compared with standards such as gallic acid, ascorbic acid and $\alpha$-acarbose.
\end{abstract}

Results: The results illustrated that all the extracts of Phyllanthus indofischeri exhibit significant antioxidant and $\alpha$-amylase inhibitory activity. Among the extracts, methanolic leaf extract showed high levels of activity followed by bark water extract.

Conclusion: Phyllanthus indofischeri extracts had shown antioxidant and $\alpha$-amylase inhibitory activity. On the basis of these results, Phyllanthus indofischeri can be used as a natural antioxidant and hypoglycemic agent against various disorders related to oxidative stress; and the isolation of bioactive compounds was warranted.

Keywords: Phyllanthus indofischeri, Antioxidant activity, $\alpha$-amylase inhibitory activity, Leaf and bark, Total phenolic content, Total flavonoid content

(C) 2016 The Authors. Published by Innovare Academic Sciences Pvt Ltd. This is an open access article under the CC BY license (http://creativecommons.org/licenses/by/4. 0/ DOI: http://dx.doi.org/10.22159/ijpps.2016v8i11.14013

\section{INTRODUCTION}

Oxidative stress explains the relation between the free radicals and diseases [1]. The major free radicals, reactive oxygen species (ROS) and reactive nitrogen species (RNS) have a dual effect on the metabolism. An imbalance of these radical species results in the damage of proteins, lipids, nucleic acids, and cell structures [2]. This is linked with the pathogenesis of various prominent diseases like cancer, fibrosis, rheumatoid arthritis, atherosclerosis, cardiovascular diseases, hypertension, and ischemia, neurodegenerative diseases like Parkinson and Alzheimer and aging [3,4]. Chronic oxidative stress due to hyperglycemia results in dysfunction of pancreatic islet ? cell, furthermore these cells have low expression of oxidative enzymes and might be susceptible for ROS which leads to diabetes mellitus. The mechanism of diabetes is related to the oxidative stress and inflammation [5-8]. Antioxidants are one among the various defense mechanisms against oxidative stress [9]. The synthetic antioxidants, which were used in the food processing and preservation such as propyl gallate, tertiary butyl hydroquinone, butylated hydroxytoluene (BHT) and butylated hydroxy ani (ole (BHA) have been proved to be carcinogenic. Hence, there is an increasing demand for natural antioxidants that are safe, without any negative effects and those of plant origin such as polyphenolic compounds [10]. Plant phenolics are known to scavenge a variety of free radicals like hydroxyl, peroxyl, hypochlorous acids, and superoxide [11], and they act as protective agents [12,13]. Herbals and herbal extracts were used to cure various diseases. In India over 200 million people with limited access to primary health centers depend on traditional medicines, in the last few decades, various plants were studied for their medicinal properties. For many chronic diseases such as diabetes, Mellitus phytotherapy is considered as one of the best alternative [14]. At present nearly 400 plants were used as antidiabetic [15]. However, the plants which were scarcely used for culinary and medicinal purpose need scientific investigation. Therefore the assessment of their medicinal properties remains an interesting and useful task to find new sources of natural antioxidants and nutraceuticals.

In tropical and subtropical countries the Phyllanthus genus is well known for its pharmacological properties, which leads to treatment of various diseases for thousands of years in folklore medicine $[16,17]$. These plants were used as astringent, diuretic, antiseptic, antidiabetic, laxative, to treagonorrheaea, headache, jaundice, mammary abscess, kidney and urinary disturbances, intestinal infections, anticancer, antioxida, nephroprotective, antitumor, and antiviral agents [18-20]. Indian gooseberry, the richest source of vitamin C next to Barbados cherry is mainly collected from Phyllanthus emblica and Phyllanthus indofischeri and is one of the heavily harvested non-timber forest products of Soligas [21].

Phyllanthus indofischeri Bennet is a woody tree species endemic to Deccan plateau and certain drier forest pocket of Southern India locally known as Ittu nelli. It differentiates from Phyllanthus emblica by monoecious nature, marble green fruit with alternate, subsessile and oblong leaves. Emblica is well known for its medicinal values and widely used in various medicines due to the presence of bioactive compounds [22]. In folk medicine, these plant species were used for anemia, asthma, dropsy, earache, dyspepsia, and jaundice [23,24]. The plant has been reported to contain various bioactive compounds, possess antimicrobial and hepatoprotective activities $[25,26]$. To the authors' knowledge, there was no report on the antioxidant activity and $\alpha$-amylase inhibitory activity of Phyllanthus indofischeri. Therefore, the present study aims to investigate the antioxidant and $\alpha$-amylase inhibitory activities of Phyllanthus indofischeri along with the determination of total phenolic content [TPC] and total flavonoid content [TFC].

\section{MATERIALS AND METHODS}

\section{Plant material}

Plant material was collected from the Nallamala forest, near to Bramhamgari matam located in Kadapa district, Andhra Pradesh, India. 
The plant was identified and deposited, voucher specimen (No: 48757) in the Department of Botany, SriKrishnadevaraya University, Anantapur, Andhra Pradesh, India, as herbarium for future reference.

\section{Preparation of extracts}

Pulverized plant materials, leaf and bark of Phyllanthus indofischeri (50g) were successively extracted by using a soxhlet apparatus (Quickfit, England) with methanol and water for 6-8 hr until the solvent is colorless to ensure complete extraction. After soxhlation, methanolic leaf extract (LME), leaf water extract (LWE), bark methanolic extract (BME) and bark water extract (BWE) marc were concentrated under vacuum. The extracts were stored separately in airtight containers in the refrigerator at $4{ }^{\circ} \mathrm{C}$ for further use.

\section{Chemicals, reagents and solvents}

$\alpha$-amylase, 3,5-dinitrosalicilic acid (DNS), $\alpha$-acarbose, folin ciocaltaeus reagent, gallic acid, quercetin, DPPH, ABTS, phenazine methosulfate (PMS), nitroblue tetrazolium (NBT), were acquired from Sigma-Aldrich (St. Louis, Mo, USA). Na2CO3, AlCl3, potassium acetate, potassium persulfate, ascorbic acid, $\mathrm{KH} 2 \mathrm{PO} 4, \mathrm{NADH}, \mathrm{H} 2 \mathrm{SO} 4$, sodium phosphate, ammonium molybdate, were purchased from Hi-Media, Mumbai. Starch, sodium, potassium tartrate, $\mathrm{NaOH}$ were obtained from SRL Pvt. Ltd., Mumbai. All other unlabeled chemicals were of analytical grade.

\section{Determination of total phenolic content}

The total phenolic content was determined by using folin ciocaltaeus reagent method described by Singleton and Rossi [27] with slight modifications. An aliquot $(1 \mathrm{ml})$ of approximately diluted extracts and standard solutions of gallic acid at various concentrations ranging from $20-100 \mathrm{mg} / \mathrm{l}$ were added to a $25 \mathrm{ml}$ volumetric flask containing $9 \mathrm{ml}$ of double distilled water. $1 \mathrm{ml}$ of folin and ciocaltaeus phenol reagent was added to the mixture and shaken. After $5 \mathrm{~min}, 4 \mathrm{ml}$ of $20 \% \mathrm{~W} / \mathrm{V} \mathrm{Na}_{2} \mathrm{CO}_{3}$ was added with stirring. Immediately, the solution was then diluted to $25 \mathrm{ml}$ with double distilled water and mixed thoroughly. A reagent blank with distilled water was prepared simultaneously. After 90 min of incubation at room temperature, the absorbance was recorded by using UV-visible spectrophotometer (Evolution 201, Thermo scientific, USA.) at 750 $\mathrm{nm}$. Percentage of total phenolic content was calculated from the calibration curve of gallic acid standard and total phenolic content was expressed as mg gallic acid equivalents (GAE)/g dry weight of the extract. All samples were analyzed in triplicate.

\section{Determination of total flavonoid content}

The total flavonoid content was determined by aluminium chloride colorimetric method described by Lin and Tang [28]. Briefly, $0.5 \mathrm{ml}$ $(1 \mathrm{mg} / \mathrm{ml})$ of extracts and standard solution of quercetin, concentration ranging from $20-100 \mathrm{mg} / \mathrm{l}$ was mixed with $1.5 \mathrm{ml}$ of $95 \%$ alcohol, $0.1 \mathrm{ml}$ of $10 \% \mathrm{AlCl}_{3} .6 \mathrm{H}_{2} \mathrm{O}, 0.1 \mathrm{ml}$ of $1 \mathrm{M}$ potassium acetate and $2.8 \mathrm{ml}$ of double distilled water were added later. After incubation for $40 \mathrm{~min}$ at room temperature, the absorbance of the mixture was observed at $415 \mathrm{~nm}$ against the blank. Total flavonoid was expressed as mg quercetin equivalents $[\mathrm{QE}] / \mathrm{g}$ dry weight of the extract.

\section{Determination of antioxidant activity}

\section{Evaluation of DPPH radical scavenging activity}

The DPPH radical scavenging activity of the extracts was determined by Liu et al. [29]. Stock solutions $(10 \mathrm{mg} / \mathrm{ml})$ of plant extracts were prepared in their respective solvents, and various concentrations $(30-300 \mu \mathrm{g} / \mathrm{ml})$ were taken as samples. $1 \mathrm{ml}$ of plant extract was mixed with $1 \mathrm{ml}$ of DPPH in methanol. The mixture was shaken vigorously and incubated in the dark for $30 \mathrm{~min}$. simultaneously control was maintained by replacing the sample with methanol. The absorbance was measured at $517 \mathrm{~nm}$. Gallic acid was used as positive control. The DPPH radical scavenging activity was determined by using the formula,

$$
\mathrm{DPPH} \%=\frac{\mathrm{A}_{\mathrm{c}}-\mathrm{A}_{\mathrm{s}}}{\mathrm{A}_{\mathrm{c}}} \times 100 .
$$

DPPH \% is the percentage of DPPH radical scavenging activity, $A_{c}$ is the absorbance of control, and $A_{s}$ is the absorbance of the sample.
The inhibition curve was plotted and $\mathrm{IC}_{50}$, the concentration necessary for $50 \%$ reduction of DPPH radical was determined.

\section{Evaluation of radical scavenging activity by ABTS}

The ABTS radical scavenging assay was performed by the method described by Re et al. [30]. ABTS radical (ABTS*) was generated by mixing equal proportions of $7 \mathrm{mmol} / \mathrm{l}$ ABTS and $2.45 \mathrm{mmol} / \mathrm{l}$ potassium persulphate via incubation for a period of $12-16 \mathrm{~h}$ in the dark at room temperature. $1 \mathrm{ml}$ of ABTS* solution was diluted with $60 \mathrm{ml}$ of methanol to obtain absorption of $0.708 \pm 0.001$ units at 745 nm using a spectrophotometer. Then $1 \mathrm{ml}$ of ABTS* solution was added to $1 \mathrm{ml}$ of plant extract and incubated for $15 \mathrm{~min}$ at room temperature, and the absorbance was measured at $745 \mathrm{~nm}$. ABTS* solution was freshly prepared for each extract. The disappearance of ABTS* determines the decrease in absorbance. The absorbance was taken within $6 \mathrm{~min}$. Then the final absorbance was noted. Ascorbic acid was used as a standard. The percentage of ABTS free radical scavenging activity was calculated by the formula,

$$
\text { ABTS } \%=\frac{1-A_{\mathrm{s}}}{A_{c}} * 100 .
$$

ABTS $\%$ is the inhibition percentage of ABTS radical, $A_{s}$ is the absorbance of the sample, $A_{c}$ is the absorbance of control. The antioxidant capacity of plant extracts was expressed as IC $\mathrm{I}_{50}$, the concentration necessary for $50 \%$ reduction of ABTS radical.

\section{Superoxide radical scavenging activity}

The superoxide radical scavenging activity was evaluated using an improved method described by Chouhan and Singh [31]. $0.1 \mathrm{ml}$ of PMS ( $0.1 \mathrm{mmol}), 0.1 \mathrm{ml}$ of NBT (1 mmol) was mixed with different concentrations of plant extracts $(30-300 \mu \mathrm{g} / \mathrm{ml})$. The volume was finally made to $0.9 \mathrm{ml}$ with $0.05 \mathrm{M}_{2} \mathrm{HOH}_{4}$ buffer ( $\mathrm{pH} 7.4$ ). By addition of $0.1 \mathrm{ml}$ of $2 \mathrm{mmol} \mathrm{NADH}$, superoxide radicals were generated in the reaction mixture and were incubated for $10 \mathrm{~min}$ at $25^{\circ} \mathrm{C}$. The absorbance was measured at $570 \mathrm{~nm}$. Ascorbic acid was used as a standard. The percentage of generated superoxide anion scavenging activity was calculated by using the formula,

$$
\text { SOD } \%=\frac{1-A_{s}}{A_{c}} * 100 .
$$

SOD \% is the percentage of superoxide scavenging activity, $A_{s}$ is the absorbance of sample, and $\mathrm{A}_{\mathrm{c}}$ is the absorbance of control. $\mathrm{IC}_{50}$ values were calculated to determine the $50 \%$ inhibition of superoxide radicals.

\section{Evaluation of total antioxidant capacity}

The total antioxidant capacity was evaluated by phosphomolybdate assay described by Jan et al. [32]. $0.1 \mathrm{ml}$ of plant extract at various concentrations $(30-300 \mu \mathrm{g} / \mathrm{ml})$ was mixed with $1 \mathrm{ml}$ of phosphomolybdate reagent solution $(0.6 \mathrm{me} \mathrm{Sa}, 28 \mathrm{mmol}$ sodium phosphate and $4 \mathrm{mmol}$ ammonium molybdate). The test tubes were covered and incubated at $95{ }^{\circ} \mathrm{C}$ for $90 \mathrm{~min}$ in a water bath. Test tubes were removed from the water bath and cooled to room temperature. The absorbance of the reaction mixture was measured at $695 \mathrm{~nm}$. Ascorbic acid was used as a standard. Calibration graph was plotted between absorbance and concentration of ascorbic acid. Total antioxidant capacity of plant extracts was calculated from the graph and expressed as milligrams of ascorbic acid equivalent (AAE)/g dry weight of the extract.

\section{Evaluation of $\alpha$-amylase inhibitory activity}

$\alpha$-amylase inhibitory assay method was performed by using the method described by Wan et al. with slight modifications [33]. Briefly, $500 \mu \mathrm{l}$ of plant extracts of various concentrations (30-300 $\mu \mathrm{g} / \mathrm{ml}$ ) were mixed with $500 \mu \mathrm{l}$ of $\alpha$-amylase (E. C 3.2.1.1) and preincubated in $20 \mathrm{mmol}$ sodium phosphate buffer (pH 6.7) at $37^{\circ} \mathrm{C}$ for $5 \mathrm{~min}$. To the above mixture, $1 \mathrm{ml}$ of $0.2 \%$ (W/V) starch dissolved in buffer was added and finally made up to $2 \mathrm{ml}$. The whole reaction mixture was incubated at $37{ }^{\circ} \mathrm{C}$ for $5 \mathrm{~min}$. After the incubation period, $1 \mathrm{ml}$ of DNS colour reagent $(96 \mathrm{mmol}(20 \mathrm{ml}), 5.3 \mathrm{mmol}$ sodium potassium tartrate in $2 \mathrm{M} \mathrm{NaOH}(8 \mathrm{ml})$ and deionized water $(12 \mathrm{ml})$ was added and placed in water bath at $85^{\circ} \mathrm{C}$ for $5 \mathrm{~min}$, the 
mixture was cooled to room temperature and $6 \mathrm{ml}$ of deionized water was added. $\alpha$-amylase inhibitory activity was determined by measuring the absorbance at $540 \mathrm{~nm}$. $\alpha$-acarbose, a known $\alpha$ amylase inhibitor was used as a positive control. The inhibitory activity was calculated by using the formula,

$$
\% \text { inhibition }=\frac{\mathrm{Ac}-\mathrm{As}}{\mathrm{Ac}} * 100 .
$$

$\%$ inhibition is the percentage of $\alpha$-amylase inhibitory activity, $A_{c}$ is the absorbance of control, $A_{s}$ is the absorbance of the sample.

\section{Statistical analysis}

All the experiments were performed in triplicate, and the data were expressed as mean \pm SD Results were analyzed by one-way ANOVA followed by Tukey's multiple comparison tests using Graph pad Prism version 6.07 for Windows, Graph Pad Software, San Diego, CA, USA. Differences were considered significant at $\mathrm{P} \leq 0.05$.

\section{RESULTS AND DISCUSSION}

The extraction yield, total phenolics, and total flavonoids of various extracts of Phyllanthus indofischeri are shown in table 1. Extraction yield ranges from 18.9 to $28.7 \%$. The highest yield was observed for LME, whereas the lowest for the BWE. The type of solvent used for extraction plays an important role in the isolation of bioactive compounds. Polar solvents are able to extract more polar compounds than nonpolar solvents. Methanol being a volatile and organic solvent is able to degrade plant cell wall, inhibit plant polyphenol oxidases and is able to extract a greater amount of endocellular materials than water [34,35]. The total phenolic content was ranged from $53.6 \mathrm{mg}$ to $86.2 \mathrm{mg} \mathrm{GAE} / \mathrm{g}$ dry weight of the extract. LME showed highest phenolics, whereas BME was much smaller. Phyllanthus species contain various phenolic compounds such as gallic acid, ellagic acid, pedunculagin, emblicannins and various low molecular weight compounds which are known for its biological activities [36,37].

The total flavonoid content of these extracts ranges from $70.39 \mathrm{mg}$ to $104.21 \mathrm{mg} \mathrm{QE} / \mathrm{g}$ dry weight of the extract. LME contains highest, followed by BME, and LWE contains the smallest fraction of flavonoids. The flavonoids are one type of polyphenols which are able to scavenge free radicals, chelate metal ions ( $\mathrm{Fe}, \mathrm{Cu}$ ). Recently, it was shown that the intake of flavonoids to be inversely related to the coronary heart disease and reduces lipid levels $[38,39]$. Leaf extracts exhibit more total phenolic and total flavonoid content than the bark due to the fact that leaf which is the primary site of secondary metabolism possess more polyphenolic content than the bark. These results suggest that the antioxidant and $\alpha$-amylase inhibitory activity of Phyllanthus indofischeri may be due to the presence of phenolic and flavonoid compounds.

Table 1: Percentage of yield, total phenolic content and total flavonoid content of Phyllanthus indofischeri extracts

\begin{tabular}{llll}
\hline Plant extract & Percentage of yield & TPC (mg GAE/g dry weight of extract) & TFC (mg QE/g dry weight of extract) \\
\hline LME & $28.7 \pm 1.6$ & $68.93 \pm 0.05$ & $104.216 \pm 0.71$ \\
BME & $23.6 \pm 2.9$ & $42.34 \pm 2.11$ & $76.53 \pm 2.62$ \\
LWE & $21.2 \pm 3.1$ & $51.12 \pm 3.62$ & $70.393 \pm 3.21$ \\
BWE & $18.9 \pm 2.3$ & $53.60 \pm 1.91$ & $84.21 \pm 1.84$ \\
\hline
\end{tabular}

Each value in the table is represented as mean $\pm S D(n=3)$, means not sharing the same letter are significantly different (LSD) at $P \leq 0.05$ probability level in each column. TPC= total phenolic content, TFC= total flavonoid content, $\mathrm{GAE}=$ gallic acid equivalent, $\mathrm{QE}=$ quercetin equivalent, $\mathrm{LME}=$ leaf methanolic extract of $P$. indofischeri, $\mathrm{BME}=$ bark methanolic extract of $P$. indofischeri, $\mathrm{LWE}=$ leaf water extract of $\mathrm{P}$. indofischeri, $\mathrm{BWE}=$ bark water extract of $P$. indofischeri

The radical scavenging activity of Phyllanthus indofischeri was measured by several assays such as DPPH, ABTS, superoxide scavenging, and total antioxidant capacity by phosphomolybdate method. These assays differ in terms of substrates, probes, reaction conditions and quantification methods. The activity carried under specific reaction conditions such as pressure, temperature, reaction media, co-reactants, and reference point specifies the particular reaction. Plant extract which contains different chemical compounds reflects its potential at various conditions; hence it is appropriate to use various assays to evaluate the mechanism of scavenging [40].

Table 2: Antioxidant and $\alpha$-amylase inhibitory activity of Phyllanthus inofischeri

\begin{tabular}{llllll}
\hline & & \multicolumn{2}{c}{$\mathbf{I C}_{\mathbf{5 0}} \mathbf{( \mu \mathrm { g } / \mathbf { m l } )}$} & \\
\hline $\begin{array}{l}\text { Plant } \\
\text { extracts/standard }\end{array}$ & $\begin{array}{l}\text { DPPH radical } \\
\text { scavenging assay }\end{array}$ & $\begin{array}{l}\text { ABTS radical } \\
\text { scavenging assay }\end{array}$ & $\begin{array}{l}\text { Superoxide radical } \\
\text { scavenging assay }\end{array}$ & $\begin{array}{l}\text { Total antioxidant capacity } \\
\text { (mg of AAE/g of extract) }\end{array}$ & $\begin{array}{l}\boldsymbol{\alpha} \text {-amylase } \\
\text { inhibitory assay }\end{array}$ \\
\hline LME & $148.18 \pm 1.23$ & $111.98 \pm 2.31$ & $178.29 \pm 1.22$ & $153.44 \pm 1.86$ & $175.57 \pm 0.43$ \\
BME & $340.22 \pm 0.98$ & $241.23 \pm 0.67$ & $212.90 \pm 1.75$ & $105.89 \pm 1.36$ & $252.26 \pm 1.34$ \\
LWE & $272.48 \pm 1.76$ & $166.42 \pm 0.55$ & $215.61 \pm 0.67$ & $94.72 \pm 1.22$ & $209.93 \pm 1.76$ \\
BWE & $184.69 \pm 0.88$ & $260.21 \pm 1.78$ & $251.07 \pm 1.34$ & $55.16 \pm 0.54$ & $250.24 \pm 2.01$ \\
Gallic acid & $107.07 \pm 1.09$ & - & - & - & - \\
Ascorbic acid & - & $38.12 \pm 1.54$ & $53.52 \pm 0.97$ & - & - \\
$\alpha$ acarbose & - & - & - & - & $84.73 \pm 0.49$ \\
\hline
\end{tabular}

Each value in the table is represented as mean $\pm S D(n=3)$, Means not sharing the same letter are significantly different (LSD) at $P \leq 0$. 05 probability level in each column. LME= leaf methanolic extract of. $P$. indofischeri, BME= bark methanolic extract o. $P$. indofischeri, LWE= leaf water extract of $P$. indofischeri, $\mathrm{BWE}=$ bark water extract of $P$. indofischeri

\section{DPPH radical scavenging assay}

DPPH is a stable chromogen radical which was in purple color, upon reduction by donating hydrogen atom converted to pale yellow hydrazine which is generally evaluated in organic media by measuring the decrease in absorbance at $515-528 \mathrm{~nm}$ [41]. Fig. 1A depict the results of DPPH radical scavenging activity of Phyllanthus indofischeri. These extracts show a concentration-dependent response of scavenging. The LME has highest scavenging ability followed by BWE, LWE and BME with an $\mathrm{IC}_{50}$ value of 148.18 , $184.69,272.48,340.22 \mu \mathrm{g} / \mathrm{ml}$, respectively, whereas, the gallic acid which was used as a standard shows an $\mathrm{IC}_{50}$ value of $107.77 \mu \mathrm{g} / \mathrm{ml}$.
These results are in agreement with other similar reports of strong DPPH radical scavenging activity of Phyllanthus species [42-44].

\section{ABTS radical scavenging assay}

This method is applicable for both hydrophilic and lipophilic antioxidants. It is a decolourization technique in which radical is generated directly into a stable form prior to reaction with putative antioxidants. The ABTS* is a blue/green color chromophore was developed by the reaction between ABTS and persulphate, with absorption maxima at $745 \mathrm{~nm}$. Percentage of inhibition of ABTS* is directly proportional to decolourisation and radical scavenging activity 
of the extract [30]. Fig. 1B shows that the extracts of Phyllanthus indofischeri have good antioxidant potential against ABTS radical with respect to IC 50 values. LME $(111.98 \mu \mathrm{g} / \mathrm{ml})$ and $\mathrm{LWE}(166.42 \mu \mathrm{g} / \mathrm{ml})$ exhibited highest antioxidant activities compared to BME (241.23 $\mu \mathrm{g} / \mathrm{ml})$ and BWE $(260.21 \mu \mathrm{g} / \mathrm{ml})$. Ascorbic acid, which was used as a positive control had shown an IC 50 value of $38.12 \mu \mathrm{g} / \mathrm{ml}$, which is very effective when compared to the extracts. Our results are in concordance with similar reports of Phyllanthus niruri [43] which has potential ABTS radical scavenging activity. Prieto et al. [45] concluded that phenolic compounds were responsible for scavenging of ABTS*. Therefore, the antioxidant capacity of the extracts can be attributed to the polyphenols which play a vital role as antioxidant in living systems due to the para and ortho positions of hydroxyl groups.

\section{Superoxide radical scavenging assay}

Fig. 1C indicates that the extracts of Phyllanthus indofischeri had good inhibitory potential against Riboflavin-NBT-light system in vitro. The scavenging potential of extracts were in the following order $\mathrm{LME}>\mathrm{BME}>\mathrm{LWE}>\mathrm{BWE}$ with an $\mathrm{IC}_{50}$ value of $178.29,212.90$ $215.61,251.07 \mu \mathrm{g} / \mathrm{ml}$ respectively in dose-dependent manner. The positive control ascorbic acid had an $\mathrm{IC}_{50}$ value of $53.52 \mu \mathrm{g} / \mathrm{ml}$, which is more effective than that of extracts. Such crude extract superoxide radical scavenging properties are shown by some other plants $[46,47]$. This assay was originally reported by Beauchamp and Fridovich, the sensitivity and specificity of this assay are quite remarkable. In the presence of oxidizable substances, the riboflavin undergoes reduction, which on reoxidation in air reduces flavins to generate $\mathrm{O}_{2}{ }^{-}$, and reduces the colorless NBT to blue formazon [48].
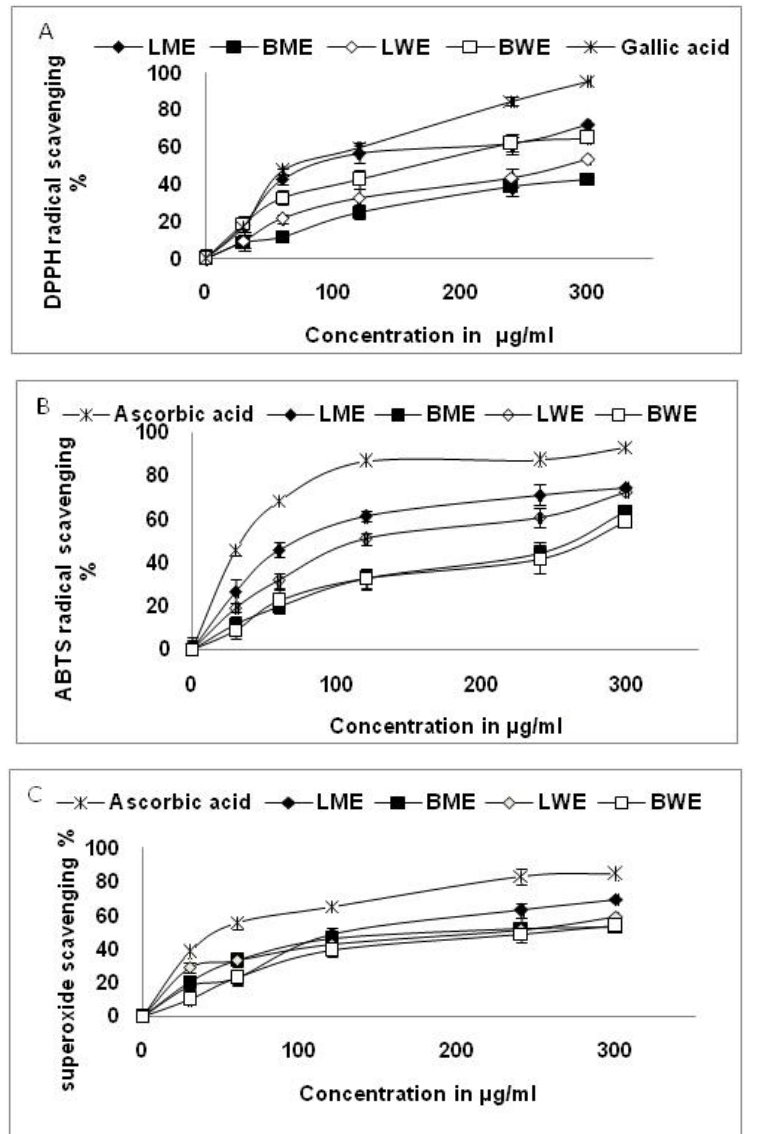

Fig. 1: Antioxidant activities of Phyllanthus indofischeri with various extracts of leaf and bark at different concentrations.

Each value represents a mean $\pm S D(n=3) ; A$. DPPH radical scavenging activity $B$. ABTS radical scavenging activity $C$. superoxide radical scavenging activity. LME= leaf methanolic extract of $P$. indofischeri, BME= bark methanolic extract of $P$. indofischeri, $L W E=$ leaf water extract of $P$. indofischeri, BWE= bark water extract of $P$. indofischeri

\section{Total antioxidant capacity by phosphomolybdate assay}

The total antioxidant capacity was stated in terms of AAE/g of dry extract; fig 2 shows the total antioxidant capacity of Phyllanthus indofischeri extracts by phosphomolybdate method. The antioxidant capacity ranges from 55.16 to $153.44 \mathrm{AAE} / \mathrm{g}$ dry weight of the extract. LME had shown the highest, whereas BWE was least among the extracts. Phosphomolybdate assay is very simple and quantitative in nature, hydrogen and electron transfer occurs from oxidant to molybdenum (VI) to convert it into molybdenum (V) green phosphate, which is measured spectrophotometrically. In general, this method uses to detect antioxidants such as vitamin C, E and some specific phenols $[45,49,50]$.

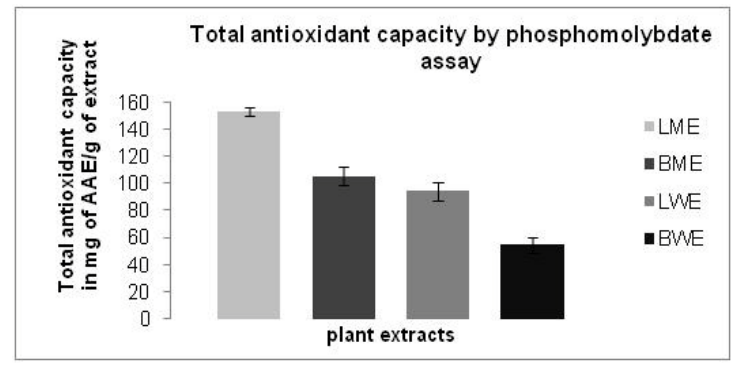

Fig. 2: Total antioxidant capacity of Phyllanthus indofischeri by Phosphomolybdate assay. Each value represents a mean \pm SD (n=3); LME= leaf methanolic extract of $P$. indofischeri, BME= bark methanolic extract of $P$. indofischeri, $L W E=$ leaf water extract of $P$. indofischeri, BWE $=$ bark water extract of $P$. indofischeri

\section{$\alpha$-amylase inhibitory assay}

All the extracts tested were positive for porcine pancreatic amylase inhibition in dose-dependent manner. Fig. 3 shows the inhibitory percentage of extracts of Phyllanthus indofischeri in comparison with the reference drug $\alpha$-acarbose. The $\alpha$-amylase inhibitory activities are in following order LME $>$ LWE $>$ BWE $>$ BME with an $\mathrm{IC}_{50}$ value of $175.57,209.93,250.24,252.26 \mu \mathrm{g} / \mathrm{ml}$ and inhibitory percentages of $46.64,38.98,35.92,32.94$ respectively. The standard drug acarbose had an $\mathrm{IC}_{50}$ value of $84.73 \mu \mathrm{g} / \mathrm{ml}$ and inhibitory percentage of 58.21, which was much greater than the plant extracts. Still the extracts the Phyllanthus indofischeri revealed their potential hypoglycemic activity.

The retardation of the breakdown of glucose and absorption by $\alpha$ amylase is one of the therapeutic approaches available for diabetes mellitus. Most of the drugs available had side effects such as abdominal distention, flatulence, meteroism, possibly diarrhea. The standard drug $\alpha$-acarbose used in the study as a positive control was a strong competitive inhibitor of $\alpha$-amylase due to the presence of pseudoring and glycosidic nitrogen linkage. It mimics the transition state of enzymatic cleavage of glycosidic bond [51]. The $\alpha$-acarbose directly interacts with the active site (Glu 233, Asp 300 and Asp 197) of $\alpha$-amylase to inhibit its activity [52]. The plant phenolic compounds are known to be potential $\alpha$-amylase inhibitors due to the fact that the phenolic compounds bind to the reactive sites of the enzymes and alter its catalytic activity [53]. Some fruits and vegetables are considered as antihyperglycemic agents due to the presence of phenolic compounds [54]. The Phyllanthus species are well known for its medicinal importance, and plants such as $P$. amarus, $P$. niruri, $P$. emblica, $P$. maderaspatensis, $P$. urinaria are reported for its $\alpha$-amylase inhibitory activity [55-59].

In the present study, correlations between the antioxidant and total phenolic content, and $\alpha$-amylase inhibitory activities and total phenolic content were observed. They were in agreement with other such reports [60,61]. The antioxidant activity of polyphenolic compounds was due to the redox properties, which can play an important role in absorbing, neutralizing, and quenching of singlet, triplet oxygen or decomposing peroxides and other radicals [62-65]. 


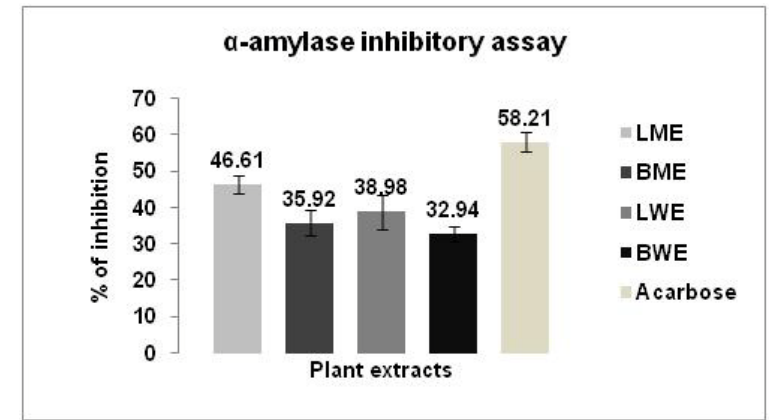

Fig. 3: $\alpha$-amylase inhibitory activity of Phyllanthus indofischeri. Each value represents a mean $\pm S D(n=3)$; $L M E=$ leaf methanolic extract of $P$. indofischeri, BME= bark methanolic extract of $P$. indofischeri, LWE= leaf water extract of $P$. indofischeri, BWE= bark water extract of $P$. indofischeri

\section{CONCLUSION}

In conclusion, the present study reveals that the extracts of Phyllanthus indofischeri exhibited significant antioxidant, free radical scavenging, and $\alpha$-amylase inhibitory activities. Leaf methanolic extract had the highest activity followed by bark water extract which are in correlation with the total phenolic content. Therefore, Phyllanthus indofischeri can be suggested as a potential natural source as an antioxidant and hypoglycemic agent. Natural source of antioxidant and hypoglycemic agents in Phyllanthus indofischeri can be attributed to its phenolic and flavonoid contents. The presence of phenolic and flavonoid contents also validates its ethnomedicinal use. Further studies are warranted for the isolation, identification, and characterization of active principles.

\section{ACKNOWLEDGEMENT}

The authors wish to express their thanks to University Grants Commission, Govt., of India, New Delhi for providing financial assistance to carry out this work.

\section{CONFLICT OF INTERESTS}

We declare that we have no conflict of interest

\section{REFERENCES}

1. Sies H. Biochemistry of oxidative stress. Angew Chem Int Ed 1986;25:1058-71.

2. Valko M, Leibfritz D, Moncol J, Cronin MTD, Mazur M, Telser J. Free radicals and antioxidants in normal physiological functions and human disease. Int J Biochem Cell Biol 2007;39:44-84.

3. Halliwell B, Gutteridge JMC. Free radicals in biology and medicine. 3rd ed. Oxford (UK): Oxford University Press; 1999.

4. Keerthana G, Kalaivani MK, Sumathy A. In vitro alpha-amylase inhibitory and antioxidant activities of ethanolic leaf extract of croton bonplandianum. Asian J Pharm Clin Res 2013;6:32-26.

5. Lenzen S, Drinkgren J, Tiedg M. Low antioxidant enzyme gene expression in pancreatic islets compared with various other mouse tissues. Free Radicals Biol Med 1996;20:463-6.

6. Tiedge M, Lortz S, Drinkgren J, Lenzens S. Relation between antioxidant enzyme gene expression and antioxidant defense status of insulin-producing cells. Diabetes 1997;46:1733-42.

7. Tanaka Y, Gleason CE, Tran POT, Harmon JS, Robertson P. Prevention of glucose toxicity in HIT-T15 cells and Zucker diabetic fatty rats by antioxidants. Proc Natl Acad Sci USA 1999;96:10857-62.

8. Matsuoka T, Kajimoto Y, Watada H, Kaneto H, Kishimoto M, Umayahara $\mathrm{Y}$, et al. Glycation-dependent, reactive oxygen species-mediated suppression of the insulin gene promoter activity in HIT cells. J Clin Invest 1997;99:144-50.

9. Cadens E, Davies KJA. Mitochondrial free radical generation, oxidative stress, and aging. Free Radicals Biol Med 2000;29:222-30.

10. Anagnostopoulou MA, Kefalas P, Papageorgiou VP, Assimopoulou AN, Boskou D. Radical scavenging activity of various extracts and fractions of sweet orange peel (Citrus sinensis). Food Chem 2006;94:19-25.

11. Halliwell B. Dietary polyphenols: good, bad, or indifferent for your health. Cardiovasc Res 2007;73:341-7.

12. Claudine M, Gary W, Christine M, Augustin S, Christian R. Bioavailability and bioefficacy of polyphenols in humans. I. Review of 97 bioavailability studies1-3. Am J Clin Nutr 2005;81:230-42.

13. Khatua S, Roy T, Acharya K. Antioxidant and free radical scavenging capacity of phenolic extract from Fussula laurocerasi. Asian J Pharm Clin Res 2013;6:156-60.

14. Rupeshkumar M, Kavitha K, Halda PK. The role of herbal plants in the diabetes mellitus therapy: an overview. Int J Appl Pharm 2014;6:1-3.

15. Sales PM, Souza PM, Simeoni LA, Magalhaes PO, Silveira D. $\alpha-$ Amylase Inhibitors: a review of raw material and isolated compounds from plant Source. J Pharm Pharm Sci 2012;15:141-83.

16. Calixto JB, Santos AR, Cechinel VF, Yunes RA. A review of the plants of the genus Phyllanthus: their chemistry, pharmacology, and therapeutic potential. Med Res Rev 1998;18:225-58.

17. Unander DW, Webster GL, Blumberg BS. Usage and bioassays in Phyllanthus (Euphorbiaceae): IV. Clustering of antiviral uses and other effects. J Ethnopharmacol 1995;45:1-18.

18. Thyagarajan SP, Jayaram P. Natural history of Phyllanthus amarus in the treatment of hepatitis B. Indian J Med Microbiol 1992;10:64-80.

19. Prakash A, Satyan KS, Wahi SP, Singh RP. The comparative hepatoprotective activity of three Phyllanthus species, $P$. urinaria, $P$. amarus and $P$. simplex on carbon tetrachloride induced liver injury in the rats. Phytother Res 1995;9:594-6.

20. Bashir MK, Ismail S, Ma HQ, Abdullah NH, Abas Hussain HJ. The in vitro and ex vivo effect of Phyllanthus niruri methanol extract on hepatic glutathione s-transferase activity in STZ induced diabetic sprague dawley rats. Asian J Pharm Clin Res 2015;8:156-9.

21. Aditi S, Solange B. Assessing sustainability of nontimber forest product extractions: how fire affects sustainability. Biodiversity Conservation 2005;14:3537-63.

22. Kaur R, Arora S. Alkaloids-important therapeutic secondary metabolites of plant origin. J Crit Rev 2015;2:1-8.

23. Narasimhudu CL, Raju RRV. Medico botanical properties of Phyllanthus species (Euphorbiaceae) used by aboriginal Adivasis of Eastern Ghats, Andhra Pradesh. Indian J Traditional Knowledge 2013;12:326-33.

24. Dnyaneshwar W, Preeti C, Kalpana J, Bhushan P. Development and application of RAPD-SCAR marker for identification of Phyllanthus emblica LINN. Biol Pharm Bull 2006;29:2313-6.

25. Srirama R, Deepak HB, Senthilkuma U, Ravikanth G, Gurumurthy BR, Shivanna MB, et al. Hepatoprotective activity of Indian Phyllanthus. Pharm Biol 2012;50:948-53.

26. Anitha S, Kalpana S. The phytochemical screening and antimicrobial activities of a medicinal plant Phyllanthus indofischeri bennet. Int J Anal Pharm Biomed Sci 2014;3:13-8.

27. Singleton VL, Rossi JA. Colorimetry of total phenolics with phosphomolybdic-phosphotungstic acid reagents. Am J Enol Vitic 1965;16:144-58.

28. Lin JY, Tang CY. Determination of total phenolic and flavonoid contents in selected fruits and vegetables, as well as their stimulatory effects on mouse splenocyte proliferation. Food Chem 2007;101:140-7.

29. Liu X, Cui C, Zhao M, Wang J, Luo W, Yang B, et al. Identification of phenolics in the fruit of emblica (Phyllanthus emblica L.) and their antioxidant activities. Food Chem 2008;109:909-15.

30. Re R, Pellegrini N, Proteggente A, Pannala A, Yang M, RiceEvans C, et al. Antioxidant activity applying an improved ABTS radical cation decolorization assay. Free Radical Biol Med 1999;26:1231-7.

31. Chouhan HS, Singh SK. Phytochemical analysis, antioxidant and anti-inflammatory activities of Phyllanthus simplex. J Ethnopharmacol 2011;137:1337-44.

32. Jan S, Khan MR, Rashid U, Bokhari J. Assessment of antioxidant Potential, total phenolics and flavonoids of different solvent fractions of Monotheca Buxifolia fruit. Osong Public Health Res Perspectives 2013;4:246-54.

33. Wan LS, Chen CP, Xiao ZQ, Wang YI, Min QX, Yue Y, et al. In vitro and in vivo antidiabetic activity of Swertiakouitchensis extract. J Ethnopharmacol 2013;147:622-30. 
34. Lim YY, Murtijaya J. Antioxidant properties of Phyllanthus amarus extracts as affected by different drying methods. LWT Food Sci Technol 2007;40:1664-9.

35. Sabir SM, Rocha JBT. Water-extractable phytochemicals from Phyllanthus niruri exhibit distinct in vitro antioxidant and in vivo hepatoprotective activity against paracetamol-induced liver damage in mice. Food Chem 2008;111:845-51.

36. Nishiura JL, Campos AH, Boim MA, Heilberg IP, Scho N. Phyllanthus niruri normalizes elevated urinary calcium levels in calcium stone forming (CSF). Patients Urol Res 2004;32:362-6.

37. Filipiakszok A, Kurzawa M, Szlyk E. Determination of antioxidant capacity and content of phenols, phenolic acids, and flavonols in Indian and European gooseberry. Chem Pap 2012;66:259-68.

38. Hertog MG, Kromhout D, Aravanis C, Blackburn H, Buzina R, Fidanza $\mathrm{F}$, et al. Flavonoid intake and long-term risk of coronary heart disease and cancer in the seven countries study. Arch Intern Med 1995;155:381-6.

39. Anila L, Vijayalakshmi NR. Flavonoids from Emblica officinalis and Mangifera indica-effectiveness for dyslipidemia. J Ethnopharmacol 2002;79:81-7.

40. Conforti F, Statti GA, Tundis R, Loizzo MR, Menichini F. In vitro activities of Citrus medica L. cv. diamante (Diamante citron) relevant to treatment of diabetes and Alzheimer's disease. Phytother Res 2007;21:427-33.

41. Magalhaes LM, Segundo MA, Reis S, Lima JL. Methodological aspects about in vitro evaluation of antioxidant properties. Anal Chim Acta 2008;613:1-19.

42. Kumaran A, Karunakaran RJ. In vitro antioxidant activities of methanol extracts of five Phyllanthus species from India. LWT Food Sci Technol 2007;40:344-52.

43. Amin ZA, Abdulla MA, Ali HM, Alshawasha MA, Qadirc SW Assessment of in vitro antioxidant, antibacterial and immune activation potentials of aqueous and ethanol extracts of Phyllanthus niruri. J Sci Food Agric 2012;92:1874-7.

44. Arshya H, Salman Khan M, Sajid Khan M, Hassan Baig M, Saheem A. Antioxidant and $\alpha$-amylase inhibitory property of Phyllanthus virgatus L.: an in vitro and molecular interaction study. BioMed Res Int 2013;729393:1-12.

45. Prieto P, Pineda M, Aguilar M. Spectrophotometric quantitation of antioxidant capacity through the formation of a phosphomolybdenum complex: specific application to the determination of vitamin E1. Anal Biochem 1999;269:337-41.

46. Harish R, Shivanandappa T. Antioxidant activity, and hepatoprotective potential of Phyllanthus niruri. Food Chem 2006; $95: 180-5$.

47. Wang BE. Treatment of chronic liver diseases with traditional Chinese medicine. J Gastroenterol Hepatol 2000;15:67-70.

48. Beauchamp C, Fridovich I. Superoxide dismutase: improved assays and an assay applicable to acrylamide gels. Anal Biochem 1971;44:276-87.

49. Muanda F, Kone D, Dicko A, Soulimani R, Younos C. Phytochemical composition and antioxidant capacity of three malian medicinal plant parts. J Evidence-Based Complementary Altern Med 2011;674320:1-8.

50. Umamaheswari M, Chatterjee TK. In vitro, antioxidant activities of the fractions of Coccinnia grandis L leaf extract. Afr J Tradit Complementary Altern Med 2007;5:61-73.
51. Rahimzadeh M, Jahanshahi S, Moein S, Moein MR. Evaluation of alpha-amylase inhibition by Urtica dioica and Juglans regia extracts. Iran J Basic Med Sci 2013;17:465-9.

52. Ashok K, Tiwari A, Rao JM. Diabetes mellitus and multiple therapeutic approaches of phytochemicals: present status and future prospects. Curr Sci 2002;83:30-8.

53. Sougata G, Mehul A, Sumersing P, Amit J, Meenakshi BD, Bimba NJ, et al. Antidiabetic activity of Gnidia glauca and Dioscorea bulbifera: potent amylase and glucosidase inhibitors. J Evidence Based Complementary Altern Med 2012;1-10. http://dx.doi.org/10.1155/2012/929051

54. Silva Pinto MD, Kwon YI, Apostolidis E, Franco ML, Genovese MI, Kalidas S, et al. Potential of Ginko biloba L. leaves in the management of hyperglycemia and hypertension using in in vitro models. Bioresour Technol 2009;100:6599-609.

55. Kumar KPS, Bhowmik D, Dutta A, Yadav APD, Paswan S, Srivastava $\mathrm{S}$, et al. Recent trends in potential traditional Indian herbs Emblica officinalis and its medicinal importance. J Pharmacogn Phytochem 2012;1:24-32.

56. Bagalkotkar G, Sagineedu SR, Saad MS, Stanslas J. Phytochemicals from Phyllanthus niruri Linn and their pharmacological properties. J Pharm Pharmacol 2006;58:1559-70.

57. Ali H, Houghton PJ, Soumyanath A. Alpha-amylase inhibitory activity of some Malaysian plants used to treat diabetes; with particular reference to Phyllanthus amarus. J Ethnopharmacol 2006;107:449-55.

58. Maria DPT, Gunawan P, Eisuke K, Jun K. $\alpha$-Amylase inhibitors from an Indonesian medicinal herb, Phyllanthus urinaria. J Sci Food Agric 2012;92:606-9.

59. Divya K, Ankur R, Seema R, Khan MU. Pleiotropic multifaceted therapeutic potential of Phyllanthus amarus. J Pharm Biol Arch 2011;2:610-4.

60. Kwon YI, Vattem DA, Shetty K. Evaluation of clonal herbs of Lamiaceae species for management of diabetes and hypertension. Asia Pac J Clin Nutr 2006;15:107-18.

61. Maher M, Dabbas A, Kitahara K, Suganuma T, Hashimoto F Tadera $\mathrm{K}$, et al. Antioxidants and alpha amylase compounds from aerial parts of Varthemia iphinoides. Boiss Biosci Biotechnol Biochem 2006;70:2178-84.

62. Sahreen S, Khan MR, Khan RA. Evaluation of antioxidant activities of various solvent extracts of Carissa opaca fruits. Food Chem 2010;122:1205-11.

63. Khan RA, Khan MR, Sahreen S, Ahmed M. Evaluation of phenolic contents and antioxidant activity of various solvent extracts of Sonchus asper (L.) Hill. Chem Cent J 2012;6:1-7.

64. Osawa T. Novel natural antioxidants for utilization in food and biological systems. In: Uritani I, Garcia VV, Mendoza EM. Editors postharvest biochemistry of plant food materials in the tropics. Japan Scientific Societies Press: Tokyo, Japan; 1994.

65. Vikrant A, Bharadwaj A, Sharma V. Pharmacology of some antioxidant plants from district Kangra Himachal Pradesh-a review. Int J Curr Pharm Res 2011;3:26-31.

\section{How to cite this article}

- Kalpana S, Ramakrushna B, Anitha S. Evaluation of in vitro antioxidant and $\alpha$-amylase inhibitory activity of Phyllanthus indofischeri bennet. Int J Pharm Pharm Sci 2016;8(11):131-136. 